\title{
Study on Response of G+5 Symmetric Structure Subjected to Blast Loads
}

\author{
I Krishna Chaitanya ${ }^{1, *}$, Balaji K. V. G. D², M. Pavan Kumar ${ }^{3}$, B. Sudeepthi ${ }^{4}$ \\ ${ }^{1}$ Research Scholar, GITAM (deemed to be University) and Department of Civil Engineering, Raghu Engineering College, \\ Visakhapatnam, 531162, India \\ ${ }^{2}$ Department of Civil Engineering, GITAM (deemed to be University), Visakhapatnam, 530045, India \\ ${ }^{3}$ Department of Civil Engineering, SVP Engineering College, Visakhapatnam, 530041, India \\ ${ }^{4}$ Research Scholar, GITAM (deemed to be University) and Department of Civil Engineering, Raghu Engineering College, \\ Visakhapatnam, 531162, India
}

Received September 9, 2020; Revised October 13, 2020; Accepted October 30, 2020

\section{Cite This Paper in the following Citation Styles}

(a): [1] I Krishna Chaitanya, Balaji K. V. G. D, M. Pavan Kumar, B. Sudeepthi, "Study on Response of G+5 Symmetric Structure Subjected to Blast Loads," Civil Engineering and Architecture, Vol. 8, No. 5, pp. 1086 - 1094, 2020. DOI: 10.13189/cea.2020.080535.

(b): I Krishna Chaitanya, Balaji K. V. G. D, M. Pavan Kumar, B. Sudeepthi (2020). Study on Response of G+5 Symmetric Structure Subjected to Blast Loads. Civil Engineering and Architecture, 8(5), 1086 - 1094. DOI: 10.13189/cea.2020.080535.

Copyright $\mathrm{C} 2020$ by authors, all rights reserved. Authors agree that this article remains permanently open access under the terms of the Creative Commons Attribution License 4.0 International License

\begin{abstract}
There is a need to study and design blast resistance structures as the terrorist activities are increasing day by day for all important structures. In present day scenario, accidental or intentional blast may take place at any point of time. From the recent blast in India at Pulwama in 2019, Bogota city in Colombia 2019 and Mogadishu city in Somalia 2018, there was a huge loss for human life. Hence, it is vital to understand how structures behave when they experience blast loads. In this paper the effects and behavior of a $\mathrm{G}+5$ symmetric Reinforced concrete building with surface blast for three different charge weights of 500, 1500 and $2500 \mathrm{~kg}$ TNT (Tri nitro toluene) assuming that the blast has occurred from a range of 10, 15 and 20 meters in lateral direction and analysis was done using SAP 2000 considering on the positive phase of the blast. Based on the results obtained from the study, response for variations in inter storey drift and energy absorbed by the considered structure is studied.
\end{abstract}

Keywords Blast Load, Time History Analysis, Lateral Displacement, Inter Storey Drift, Energy Absorbed

\section{Introduction}

Study on Blast effected structures has become a technical inspection and investigation, as almost from 1920-2019 there are more than 500 blast attacks had been occurred by source cars and trucks and from the recent blasts of Bogota city in Colombia 2019, Pulwama in 2019, and Mogadishu city in Somalia 2018, many buildings are collapsed and many people were killed. A catastrophic damage to the buildings externally and internally by collapsing wall is caused when blast explosion occurs within or nearby structures. There will be huge loss of life and many injuries to the residing people due to structural collapse, impact by debris, smoke along with fire. Due to these gas-chemical explosions, a large dynamic load more than the designed original loads considered on the structure will be obtained and this has become a most important consideration and challenge for designers by the global attacks. As conventional buildings are not designed to resist blast loads as we cannot scale the impact of blast as it is a sudden attack. But however, we can try to understand the performance of the structure at the time of blast from the past history and with the maximum blast impact data and can adopt new guidelines for the constructed structures and new structures too.

\section{Literature Review}

Nelson et al., [1] conducted time-history analysis on 
simple cantilever model walls, developed a capacity spectrum model for analyzing of blast loads for cantilever wall subjected to linear elastic dynamic analysis based on the function of blast pressure, and identified the correlation between clearing time and corner period of the blast.

Van der Meer [2] using ANSYS11.0 investigated the dynamic response of structures for BLEVE blast loading and blast loading to determine the mode shapes and natural frequencies. Maximum displacement is obtained at the top in static analysis. Using SDOF and MDOF method, the pressure impulse diagram and response diagram are procured for BLEVE blast loading when applied to a sample building and the base shear response, top displacement base moment is compared.

Mohamed S. Al-Ansari [3] investigated the response of structures to earthquake and blast loads. Blast loads of $1000 \mathrm{~kg}$ of TNT are applied on a six-story building at a distance of $2 \mathrm{~m}$. When an earthquake load in zone 5 is applied to a twenty- story building and analyzed, it showed similar response like it is blasted with $128 \mathrm{~kg}$ of TNT at a range of or $261 \mathrm{~kg}$ of TNT at a range of $10 \mathrm{~m}$.

Jayashree et. al [4] investigated the dynamic response of a space framed structure when it is exposed to a blast load using SIFCON by performing time history analysis for blast loads by employing SAP 2000. The results show that about $20-30 \%$ of reduction in displacement is obtained by adopting SIFCON.

Aditya Kumar et al., [5] has studied different loadings which occur during a blast and the methods used to investigate these loading phenomena. The study show that the lack of relevant code is the main reason for not adopting this phenomenon in designing the structure.

Quazi Kashif and M. B. Varma [6] studied the evolving different methods of design and structural analysis for resisting blast loads by considering a 5 storey building and the model was created using SAP 2000. A standoff of $30 \mathrm{~m}$ from explosion blast effect is calculated. Lateral load is computed and compared in terms of inter storey drift, Velocity accelerations and peak deflections showed that, performance level of building is reached to collapse Point for minimum standoff distance

Sarita Singla et al., [7] studied blast pressures for blast loads and ranges, using U.S manual, for different conditions are calculated for blast pressures by taking the interrelationship between scaled blast distance and blast pressure. With the conditions of duration of positive phase of blast and reflected total over pressure time history loading are calculated, the results reflect that the blast pressure reduces as the distance increases from the building.

Swathi ratna $\mathrm{k}$ [8] conducted a study on RCC and Simcon buildings when subjected to blast effects using time history analysis to compute the dynamic response of a structure to an arbitrary loading in ETABS. From the study it has been concluded that SIMCON buildings have much more fundamental frequency than RCC buildings.
M Pavan Kumar and K. Rambabu [9] The intent of this paper is to explore the response of RC Space Frame with vertical setback to earthquake and blast loading using Applied Element Method (AEM). From this result, it was observed that for $2500 \mathrm{~kg}$ TNT blast load the maximum $\mathrm{X}$-displacement and earthquake load are proportionate at all storeys.

Jinwon Shin and Kyungkoo Lee [10] have studied the deficiencies of SDOF design charts for near field detonations for high explosions and also investigated the consideration of uniformly distributed load for SDOF analysis for near field detonations. To solve these problems upgraded SDOF design charts which include the response to the nearfield detonations based on numerical calculations are suggested and are compared to finite element analysis results of steel component and UFC 3-34002 predictions and are verified accordingly.

Boyina sita Rama Krishna and Jinka Chandra Sekhar [11] studied the effects of blast loads on G+10 RCC structure, subjected to blast load of $10 \mathrm{~kg}$ TNT at a range of $30 \mathrm{~m}$ which is designed in SAP 2000 using nonlinear time history analysis. The results are calculated for storey drift and maximum storey displacement. It was deduced that the performance of structure joints were critical when they are close to the blast and hence Hinges are developed in all beams and columns.

Pavan Kumar and K. Rambabu [12] The aim of this work is to study the behavior of Regular RC Space Frame subjected to Earthquake and Blast loads using Applied Element Method (AEM). It is noticed from the results that for $2500 \mathrm{~kg}$ TNT blast load maximum X-Displacement and Earthquake load were equivalent at all storeys. At a duration of 5 seconds the maximum displacement occurred of a frame subjected to Northridge earthquake whereas it occurred at 0.5 seconds of a frame subjected to $2500 \mathrm{~kg}$ TNT blast load.

\section{Materials and Methods}

\subsection{Geometry of Considered Structure}

A G+5 Reinforced concrete frame building having size $22 \mathrm{~m} \times 22 \mathrm{~m}$ is considered with equal bay width of $5.5 \mathrm{~m}$ and storey height of $3 \mathrm{~m}$. Geometry details of the considered building as shown in (figure 1).

\subsection{Cross Section Details of the Structural Components}

Following are the cross-section details of various structural components of the considered building

Plinth beam size : $230 \mathrm{~mm} \times 230 \mathrm{~mm}$

Floor beam size : $230 \mathrm{~mm} \times 500 \mathrm{~mm}$

Column size $\quad: 450 \mathrm{~mm} \times 450 \mathrm{~mm}$

Slab thickness $\quad: 150 \mathrm{~mm}$ 


\subsection{Material Properties}

Grade of concrete : M30

Grade of steel : Fe415

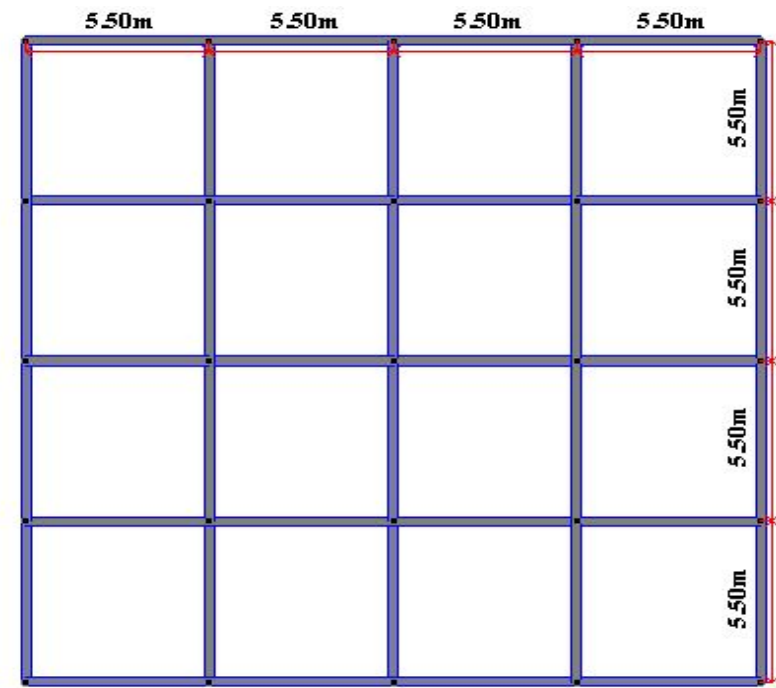

(a) Plan

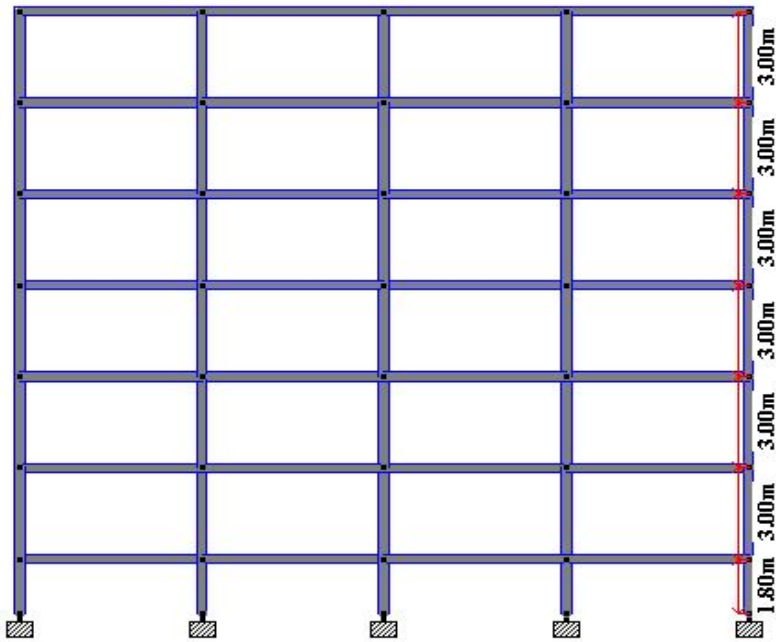

(b) Elevation

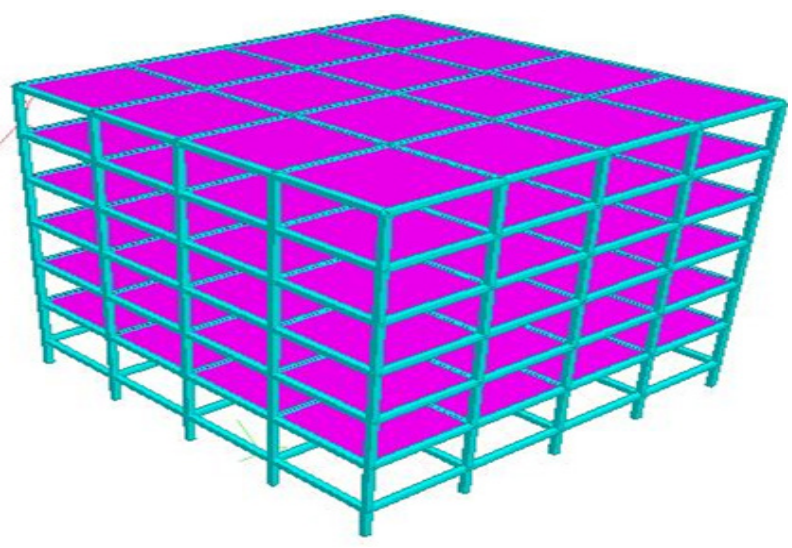

c) 3D Isometric view

Figure 1. $(a, b, c)$ Geometry views of the considered building

\subsection{Details of Loads}

Initially, analysis and design were performed on the considered building subjected to gravity loads (Dead and Live). Blast load is applied on the designed frame (as per IS:456-2000) to study the response of the structure.

\subsection{Blast Loads}

Surface blast load on structure for intensities of 500, 1500 and $2500 \mathrm{~kg}$ TNT at different ranges of 10,15 and 20 $\mathrm{m}$ are calculated based on TM-5-1300. Typical view of frame with different charge weights and ranges are shown in the (figure 2).

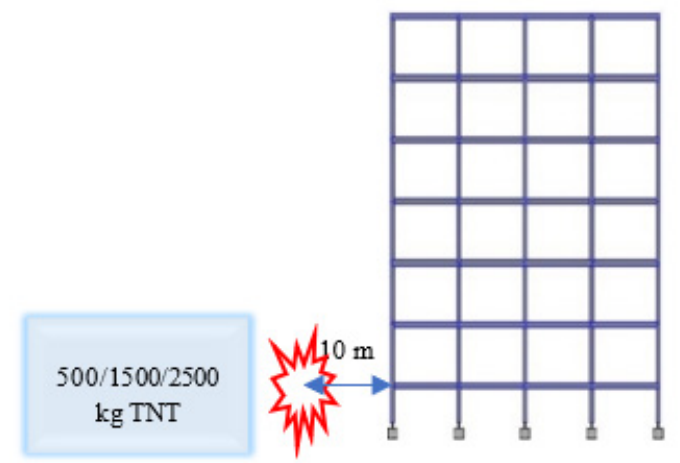

(a) For a range of $10 \mathrm{~m}$

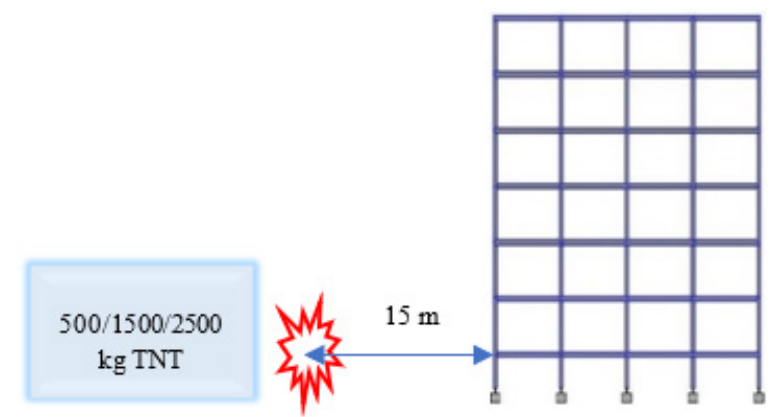

(b) For a range of $15 \mathrm{~m}$

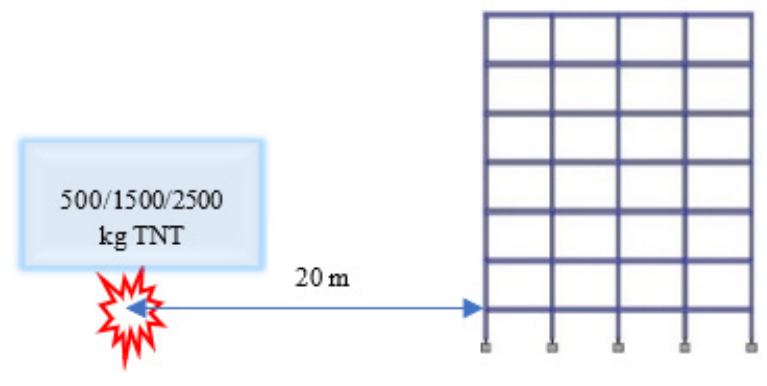

(c) For a range of $20 \mathrm{~m}$

Figure 2A. (a,b,c) Typical view of frame with different charge weights and ranges 


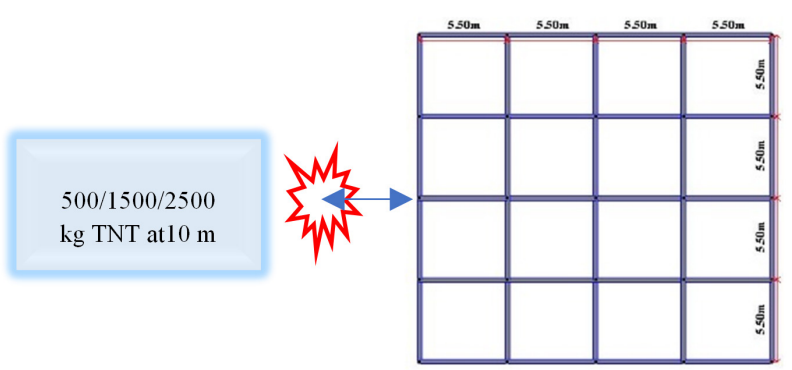

(a) At $10 \mathrm{~m}$ range

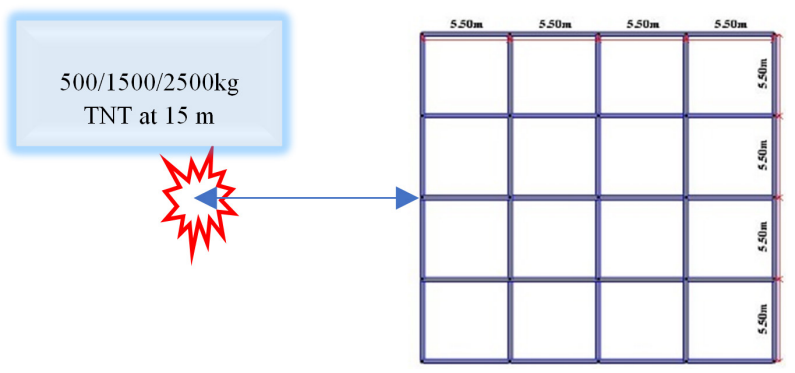

(b) At $15 \mathrm{~m}$ range

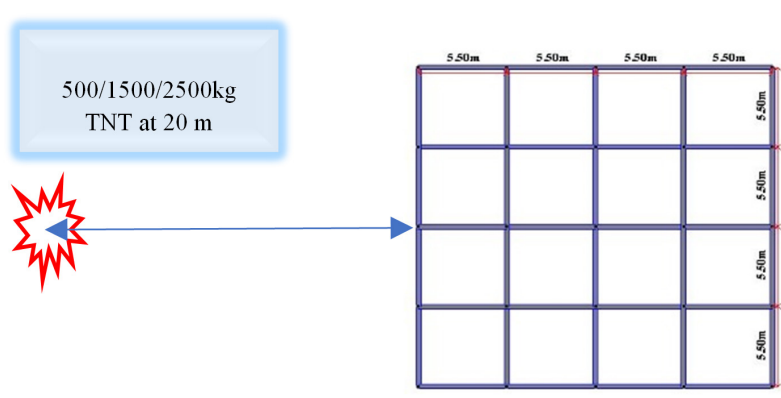

(c) At $20 \mathrm{~m}$ range

Figure 2B. $(a, b, c)$ Plan view showing the placement of the blast with different charge weights and ranges

\subsection{Analysis}

Time history analysis is performed on the considered Reinforced Concrete structure subjected to various surface blast load intensities at different ranges using SAP 2000 software package.

\section{Results and Discussions}

\subsection{Response of Structure for Blast Load of $500 \mathrm{~kg}$ TNT at a range of 10,15 and $20 \mathrm{~m}$}

\subsubsection{Lateral Displacement}

The variation of lateral displacement of the structure against blast load of $500 \mathrm{~kg}$ TNT at 10,15 and $20 \mathrm{~m}$ at different storey levels are shown in (figure 3).

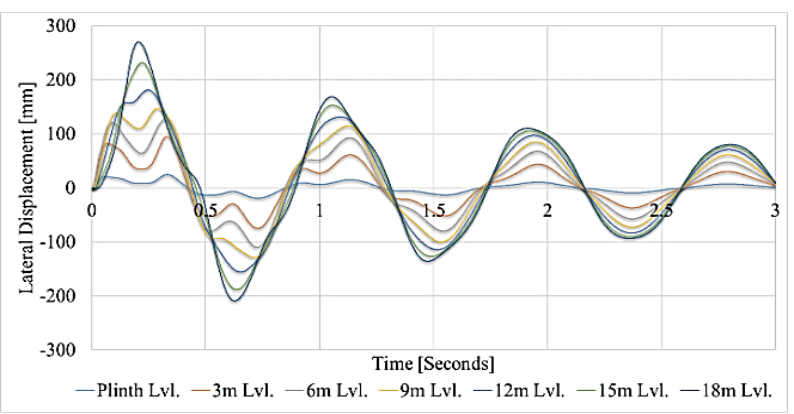

(a) At $10 \mathrm{~m}$ range

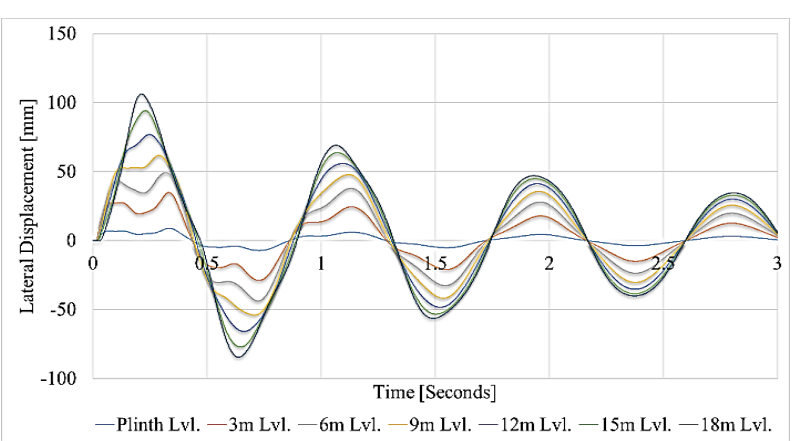

(b) At $15 \mathrm{~m}$ range

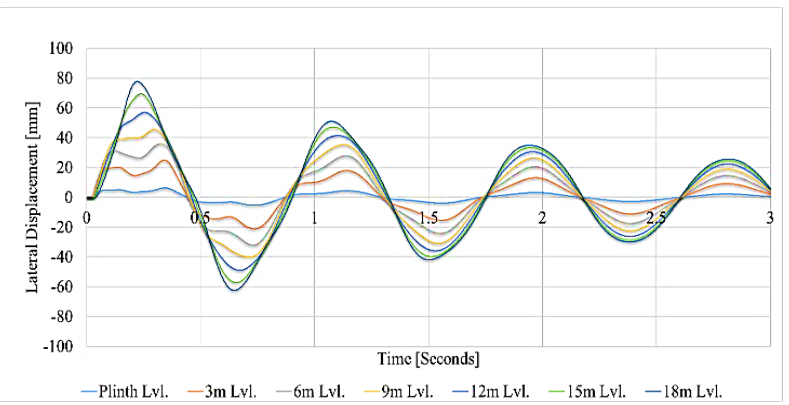

(c) At $20 \mathrm{~m}$ range

Figure 3. (a,b,c) Lateral Displacement vs Time for $500 \mathrm{~kg}$ TNT charge weight at range of 10,15 and $20 \mathrm{~m}$

\subsubsection{Inter storey drift}

From (figure 3), maximum inter storey drift is calculated for each storey of the considered structure for a charge weight of $500 \mathrm{~kg}$ TNT at a range of 10,15 and $20 \mathrm{~m}$. To know the response of the structure for $500 \mathrm{~kg}$ TNT blast, graph is plotted between ratios of maximum inter storey drift of standoff distance $15 \mathrm{~m}$ to $10 \mathrm{~m} / 20 \mathrm{~m}$ to $10 \mathrm{~m}$ vs storey level.

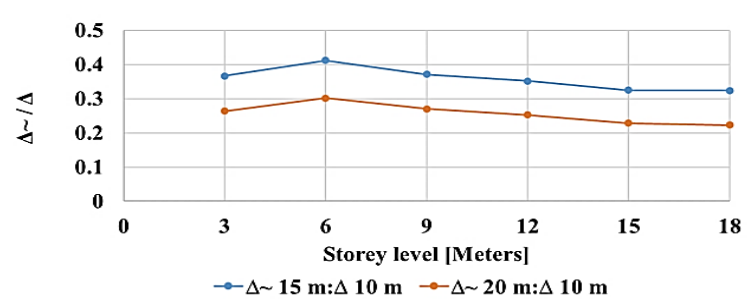

Figure 4. Inter storey drift ratios vs storey level for $500 \mathrm{~kg}$ TNT charge weight 
For a charge weight of $500 \mathrm{~kg}$ TNT, it is clearly observed from figure 4 that maximum inter storey drift ratio between standoff distances $15 \mathrm{~m}$ to $10 \mathrm{~m}$ and $20 \mathrm{~m}$ to $10 \mathrm{~m}$ is found at a storey level of $6 \mathrm{~m}$. For a standoff distance of $15 \mathrm{~m}$ and $20 \mathrm{~m}$, there is a decrease in maximum inter storey drift at every storey level when compared to $10 \mathrm{~m}$ standoff distance.

\subsubsection{Acceleration}

The variation of acceleration of the considered structure against blast load of $500 \mathrm{~kg}$ TNT at 10,15 and $20 \mathrm{~m}$ at different storey levels are shown in the (figure 5).

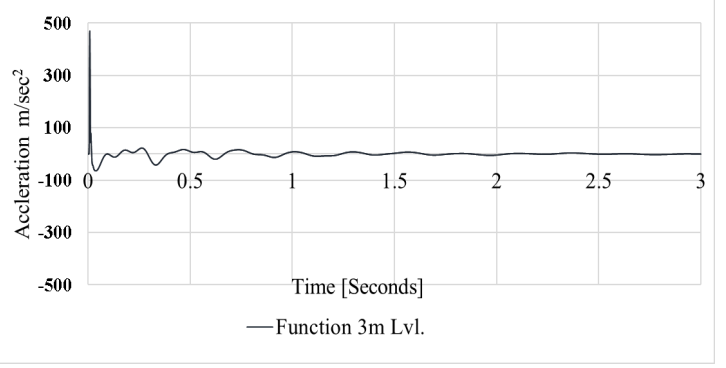

(a) At $10 \mathrm{~m}$ range

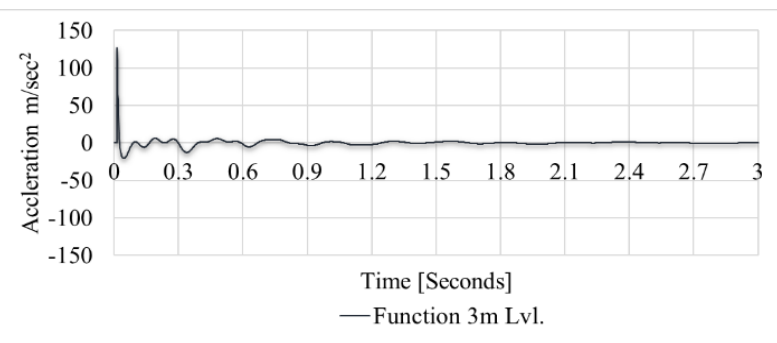

(b) At $15 \mathrm{~m}$ range

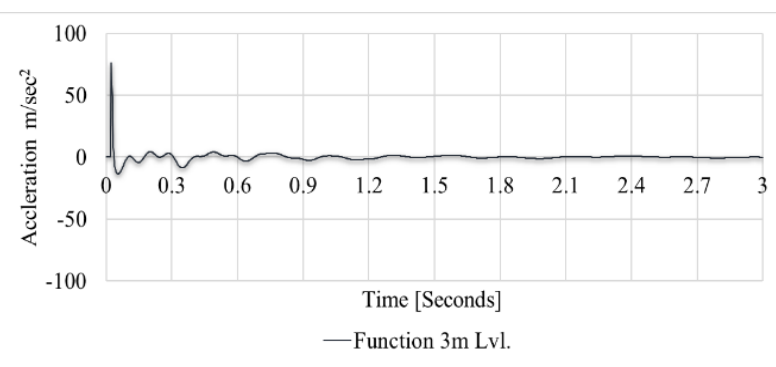

(c) At $20 \mathrm{~m}$ range

Figure 5. (a,b,c) Acceleration vs Time for $500 \mathrm{~kg}$ TNT at 10, 15 and $20 \mathrm{~m}$ ranges

\subsubsection{Energy absorbed}

From the theory of Arias intensity $\left(\mathrm{I}_{\mathrm{A}}=\frac{\pi}{2 g} \int \mathrm{a}^{2} \mathrm{dt}\right)$ which determines the intensity of shock wave by measuring the acceleration of seismic waves. Inspired from this theory, Pavan et al. [13] proposed $\left(\mathrm{a}^{2} \mathrm{dt}\right)$ to determine energy absorbed by the structure against blast. The same theory is used in this study. From the acceleration data obtained from the analysis at a storey level of $3 \mathrm{~m}$ against a blast load of $500 \mathrm{~kg}$ TNT at 10,15 and $20 \mathrm{~m}$ ranges, graph is plotted between the energy absorbed by the structure vs time as shown in (figure 6).

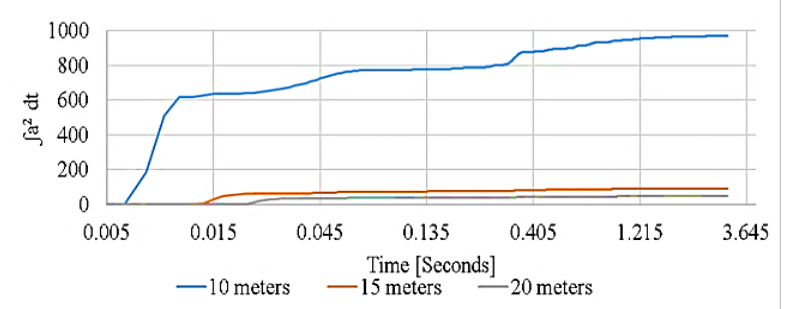

Figure 6. $\mathrm{fa}^{2} \mathrm{dt}$ vs time for $500 \mathrm{~kg}$ TNT at 10,15 and $20 \mathrm{~m}$ range

From the (figure 6), for a charge weight of $500 \mathrm{~kg}$ TNT, blast-initiated time for $15 \mathrm{~m}$ standoff distance is twice that of $10 \mathrm{~m}$ standoff distance, whereas $20 \mathrm{~m}$ is thrice that of $10 \mathrm{~m}$ standoff distance. Maximum energy absorbed by the structure for $10 \mathrm{~m}$ standoff distance is 10 times more than $15 \mathrm{~m}$ standoff distance and 20 times more than $20 \mathrm{~m}$ standoff distance. Maximum Energy absorbed by the structure for all the considered standoff distances is within 0.1 seconds.

\subsection{Response of Structure for Blast Load of $1500 \mathrm{~kg}$ TNT at a range of 10,15 and $20 \mathrm{~m}$}

\subsubsection{Lateral Displacement}

The variation of lateral displacement of the structure against blast load of $1500 \mathrm{~kg}$ TNT at 10,15 and $20 \mathrm{~m}$ at different storey levels are shown in (figure 7).

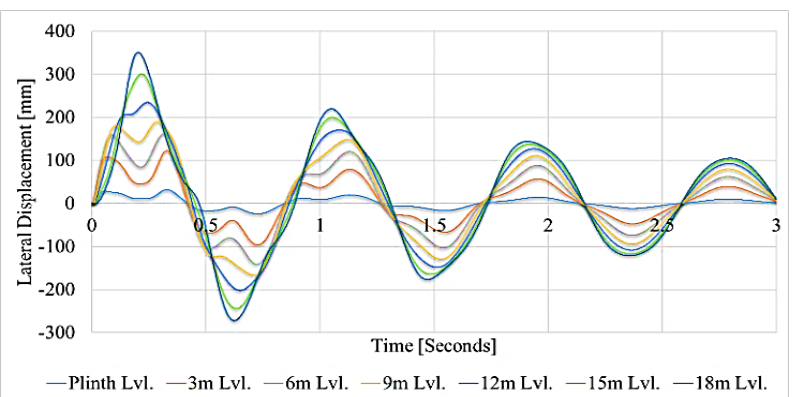

(a) At $10 \mathrm{~m}$ range

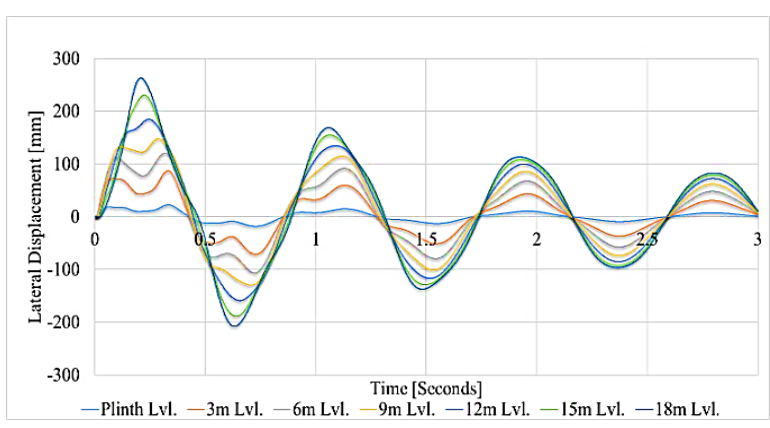

(b) At $15 \mathrm{~m}$ range 


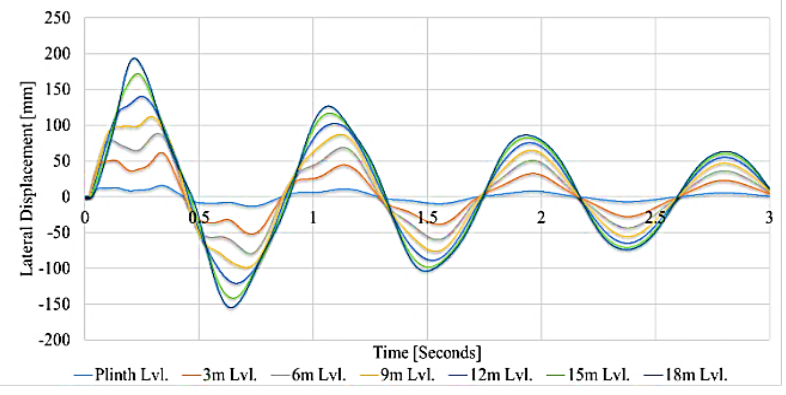

(c) At $20 \mathrm{~m}$ range

Figure 7. $(\mathrm{a}, \mathrm{b}, \mathrm{c})$ Lateral Displacement vs Time for $1500 \mathrm{~kg}$ TNT charge weight at range of 10,15 and $20 \mathrm{~m}$

\subsubsection{Inter storey drift}

From (figure 7), maximum inter storey drift is calculated for each storey of the considered structure for a charge weight of $1500 \mathrm{~kg}$ TNT at a range of 10,15 and $20 \mathrm{~m}$. To know the response of the structure for $1500 \mathrm{~kg}$ TNT blast, graph is plotted between ratios of maximum inter storey drift subjected to blast load for $15 \mathrm{~m}$ to $10 \mathrm{~m} / 20 \mathrm{~m}$ to $10 \mathrm{~m}$ vs storey level.

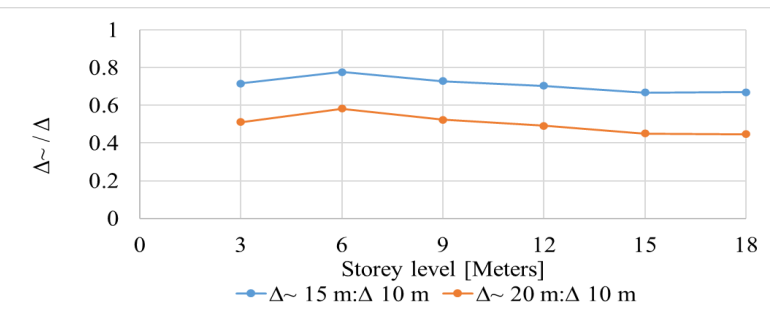

Figure 8. Inter storey drift ratios vs storey level for $1500 \mathrm{~kg}$ TNT charge weight

For a charge weight of $1500 \mathrm{~kg}$ TNT, it is clearly observed from figure 8 that maximum inter storey drift ratio between standoff distances $15 \mathrm{~m}$ to $10 \mathrm{~m}$ and $20 \mathrm{~m}$ to $10 \mathrm{~m}$ is found at a storey level of $6 \mathrm{~m}$. For a standoff distance of $15 \mathrm{~m}$ and $20 \mathrm{~m}$, there is a decrease in maximum inter storey drift at every storey level when compared to $10 \mathrm{~m}$ standoff distance.

\subsubsection{Acceleration}

The variation of acceleration of the structure against blast load of $1500 \mathrm{~kg}$ TNT at 10,15 and $20 \mathrm{~m}$ at different storey levels for the considered building are shown in (figure 9).

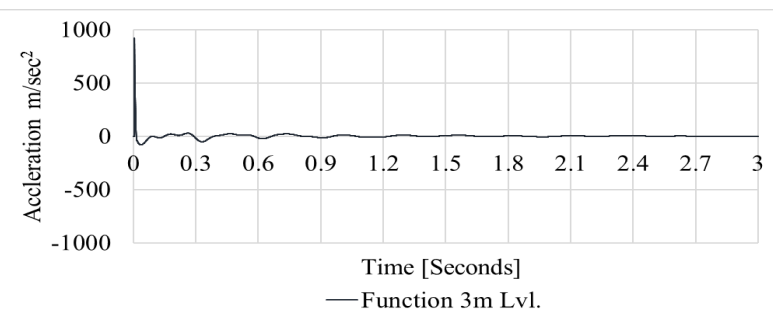

(a) At $10 \mathrm{~m}$ range

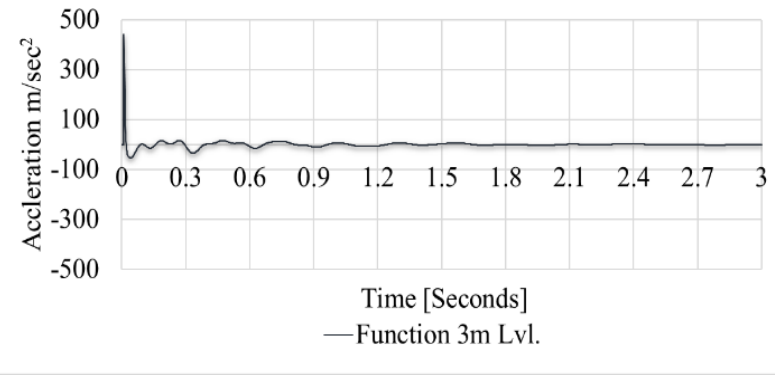

(b) At $15 \mathrm{~m}$ range

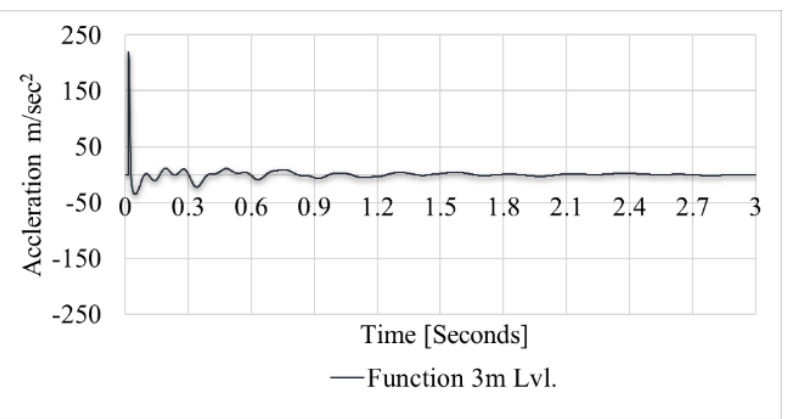

(c) At 20m range

Figure 9. Acceleration vs Time for $1500 \mathrm{~kg}$ TNT at 10,15 and $20 \mathrm{~m}$ ranges

\subsubsection{Energy absorbed}

From the acceleration data obtained from the analysis at a storey level of $3 \mathrm{~m}$ against a blast load of $1500 \mathrm{~kg}$ TNT at 10,15 and $20 \mathrm{~m}$ ranges, graph is plotted between the energy absorbed by the structure vs time as shown in (figure 10).

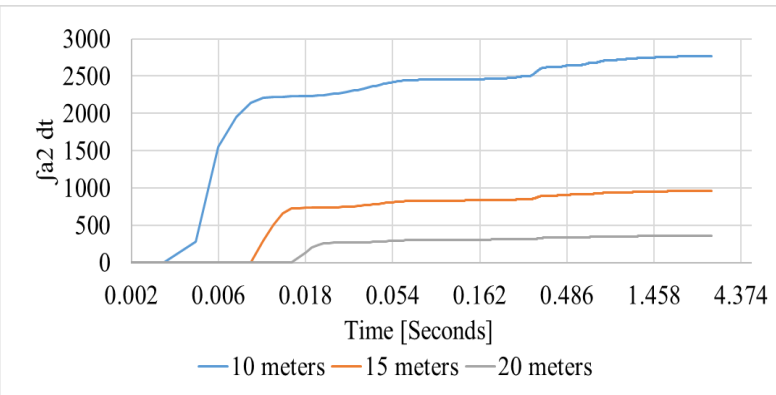

Figure 10. $\left(\mathrm{fa}^{2} \mathrm{dt}\right) \mathrm{vs}$ time for $1500 \mathrm{~kg}$ TNT at 10,15 and $20 \mathrm{~m}$ range

From the (figure 10), for a charge weight of $1500 \mathrm{~kg}$ TNT, blast-initiated time for $15 \mathrm{~m}$ standoff distance is 1.75 times that of $10 \mathrm{~m}$ standoff distance, whereas $20 \mathrm{~m}$ is 2.75 times that of $10 \mathrm{~m}$ standoff distance. Maximum energy absorbed by the structure for $10 \mathrm{~m}$ standoff distance is 10 times more than $15 \mathrm{~m}$ standoff distance and 20 times more than $20 \mathrm{~m}$ standoff distance. Eighty-six percentage of total energy absorbed by the structure is absorbed within 0.1 seconds only for all the considered standoff distances. 


\subsection{Response of Structure for Blast load of $2500 \mathrm{~kg}$ TNT at a range of 10,15 and $20 \mathrm{~m}$}

\subsubsection{Lateral Displacement}

The variation of lateral displacement of the structure against blast load of $2500 \mathrm{~kg}$ TNT at 10,15 and $20 \mathrm{~m}$ at different storey levels are shown in (figure 11).

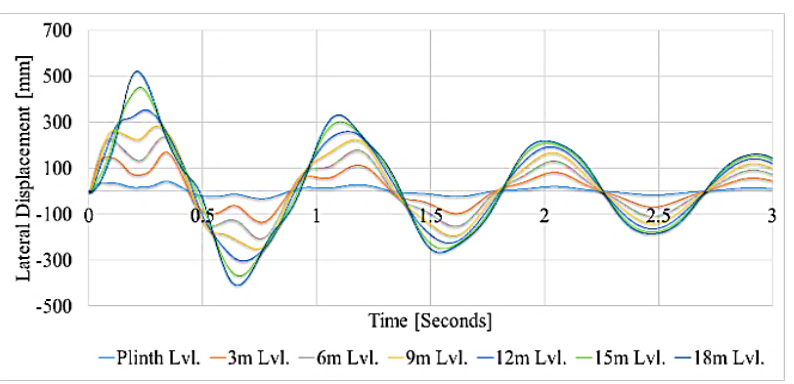

(a) At $10 \mathrm{~m}$ range

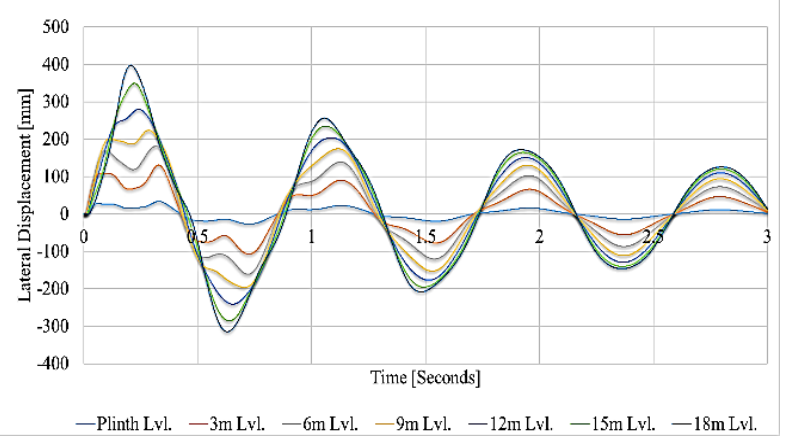

(b) At $15 \mathrm{~m}$ range

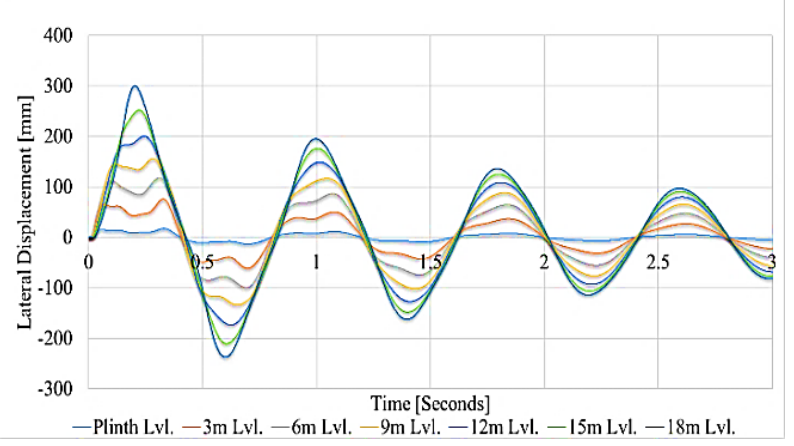

(c) At $20 \mathrm{~m}$ range

Figure 11. (a,b,c) Lateral Displacement vs Time for $2500 \mathrm{~kg}$ TNT charge weight at range of 10,15 and $20 \mathrm{~m}$

\subsubsection{Inter storey drift}

From (figure 11), maximum inter storey drift is calculated for each storey of the considered structure for a charge weight of $2500 \mathrm{~kg}$ TNT at a range of 10,15 and $20 \mathrm{~m}$. To know the response of the structure for $500 \mathrm{~kg}$ TNT blast, graph is plotted between ratios of maximum inter storey drift subjected to blast load for $15 \mathrm{~m}$ to $10 \mathrm{~m} / 20 \mathrm{~m}$ to $10 \mathrm{~m}$ vs storey level.

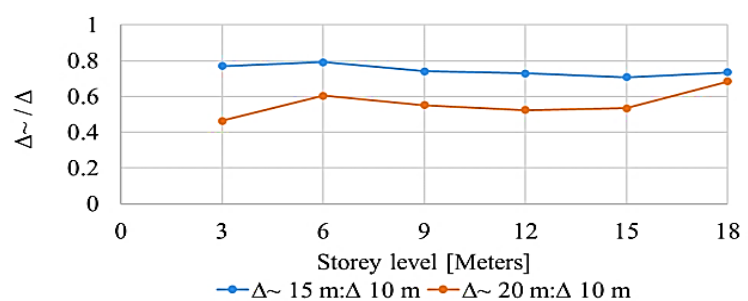

Figure 12. Inter storey drift ratios vs storey level for $2500 \mathrm{~kg}$ TNT charge weight

For a charge weight of $2500 \mathrm{~kg} \mathrm{TNT}$, it is clearly observed from figure 12 that maximum inter storey drift ratio between standoff distances $15 \mathrm{~m}$ to $10 \mathrm{~m}$ and $20 \mathrm{~m}$ to $10 \mathrm{~m}$ is found at a storey level of $6 \mathrm{~m}$. For a standoff distance of $15 \mathrm{~m}$ and $20 \mathrm{~m}$, there is a decrease in maximum inter storey drift at every storey level when compared to $10 \mathrm{~m}$ standoff distance.

\subsubsection{Acceleration}

The variation of acceleration of the structure against blast load of $2500 \mathrm{~kg}$ TNT at 10,15 and $20 \mathrm{~m}$ at different storey levels are shown in (figure 13).

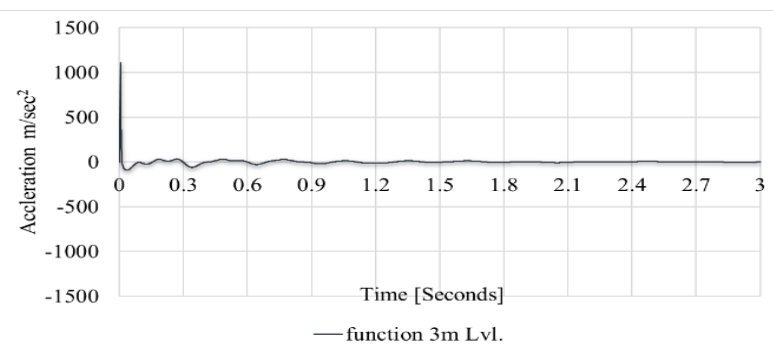

(a) At $10 \mathrm{~m}$ range

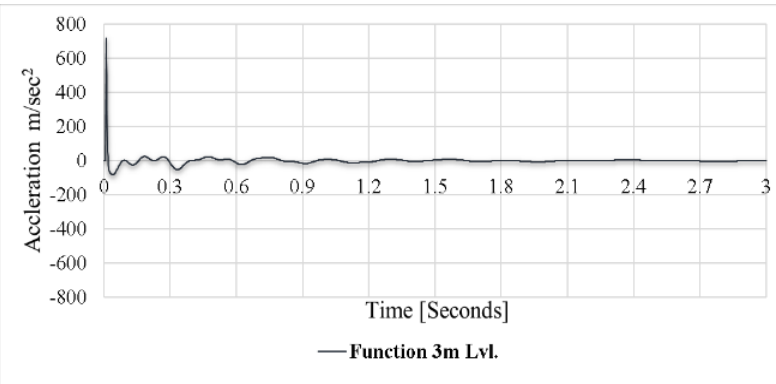

(b) At $15 \mathrm{~m}$ range

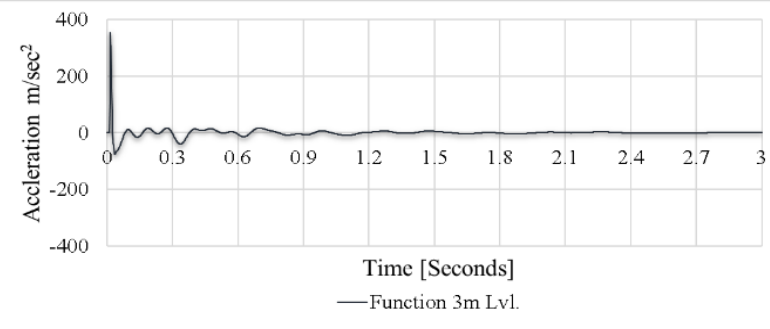

(c) At 20m range

Figure 13. Acceleration vs Time for $2500 \mathrm{~kg}$ TNT at 10,15 and $20 \mathrm{~m}$ ranges 


\subsubsection{Energy Absorbed}

From the acceleration data obtained from the analysis at a storey level of $3 \mathrm{~m}$ against a blast load of $2500 \mathrm{~kg}$ TNT at 10,15 and $20 \mathrm{~m}$ ranges, graph is plotted between the energy absorbed by the structure vs time as shown in (figure 14).

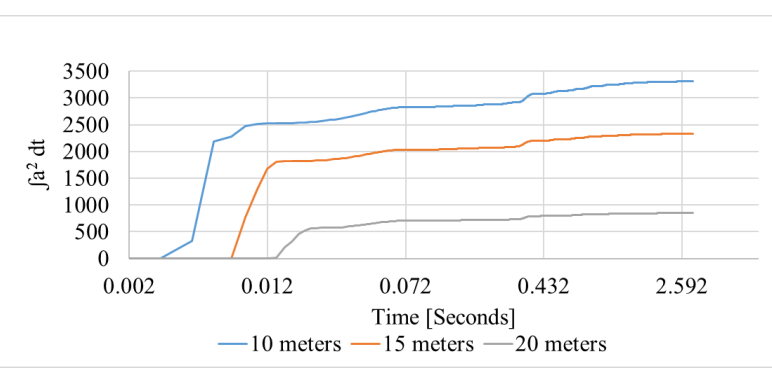

Figure 14. $\left(\mathrm{aa}^{2} \mathrm{dt}\right)$ vs time for $2500 \mathrm{~kg}$ TNT at 10,15 and $20 \mathrm{~m}$ range

From the (figure 14), for a charge weight of $2500 \mathrm{~kg}$ TNT, blast-initiated time for $15 \mathrm{~m}$ standoff distance is 1.75 times that of $10 \mathrm{~m}$ standoff distance, whereas $20 \mathrm{~m}$ is 2.5 times that of $10 \mathrm{~m}$ standoff distance. Maximum energy absorbed by the structure for $10 \mathrm{~m}$ standoff distance is 10 times more than $15 \mathrm{~m}$ standoff distance and 20 times more than $20 \mathrm{~m}$ standoff distance. Eighty-five percentage of total energy absorbed by the structure is absorbed within 0.1 seconds only for all the considered standoff distances.

\section{Conclusions}

- The structure affects significantly when there is increase in charge weight and with decrease in standoff distance.

- For a charge weight of $500 \mathrm{~kg}$ TNT maximum inter storey drift for $15 \mathrm{~m}$ and $20 \mathrm{~m}$ standoff distance is $41 \%$ and $30 \%$ of $10 \mathrm{~m}$ standoff distance respectively.

- $\quad$ For a charge weight of $1500 \mathrm{~kg}$ TNT maximum inter storey drift for $15 \mathrm{~m}$ and $20 \mathrm{~m}$ standoff distance is $77 \%$ and $58 \%$ of $10 \mathrm{~m}$ standoff distance respectively.

- $\quad$ For a charge weight of $2500 \mathrm{~kg}$ TNT maximum inter storey drift for $15 \mathrm{~m}$ and $20 \mathrm{~m}$ standoff distance is $79 \%$ and $68 \%$ of $10 \mathrm{~m}$ standoff distance respectively.

- Maximum acceleration in the considered structure is observed at a storey level of $3 \mathrm{~m}$ for all the considered surface blast loads.

- Energy absorbed by the considered structure subjected to charge weight of $1500 \mathrm{~kg}$ TNT is 2.5 times more than that of same structure subjected to charge weight of $500 \mathrm{~kg}$ TNT

- Energy absorbed by the considered structure subjected to charge weight of $2500 \mathrm{~kg}$ TNT is 3.5 times more than that of same structure subjected to charge weight of $500 \mathrm{~kg}$ TNT.

- The blast-initiated time of considered structure for $15 \mathrm{~m}$ and $20 \mathrm{~m}$ standoff distance is more than that of same structure with $10 \mathrm{~m}$ standoff distance subjected to different charge weights.

- Almost eighty percentage of energy absorbed by the structure is within 0.1 seconds time for all the considered blast loads.

\section{REFERENCES}

[1] Nelson Lam, Priyan Mendis and Tuan Ngo, Response Spectrum Solutions for Blast Loading, Electronic Journal of Structural Engineering, (2004).

[2] L. J. Van Der Meer, Dynamic Response of High-Rise Building Structures to Blast Loading, Research report, Eindhoven University of Technology, A-2008.8, April (2008).

[3] Mohamed S. Al-Ansari, Building Response to Blast and Earthquake loading, International Journal of Civil Engineering and Technology (IJCIET), Vol. 3, Issue 2, ISSN: 0976 - 6316 pp. 327 - 346, July - December (2012).

[4] Jayashree S.M, Dynamic Response of a Spaced Framed Structure Subjected to Blast Load, Journal of Civil and Structural Engineering, ISSN: 0976 - 4399, Vol. 4, Issue 1, Aug (2013).

[5] Aditya Kumar Singh, Md. Asif Akbari and P. Saha, Behavior of Reinforced Concrete Beams under Different Kinds of Blast Loading, International Journal of Civil Engineering Research. ISSN: 2278 - 3652, Vol. 5, No. 1, pp. $13-20$ (2014).

[6] Quazi Kashif and M. B. Varma, Effect of Blast on G+4 RCC Frame Structure, International Journal of Emerging Technology and Advanced Engineering, ISSN 2250-2459, Volume 4, Issue 11, November (2014).

[7] Sarita Singla, Pankaj Singla and Anmol Singla, Computation of Blast Loading for a Multi-Storeyed Framed Building, International Journal of Research in Engineering and Technology, e-ISSN: $2319-1163$, p-ISSN: $2321-7308$, (2015).

[8] Swathi ratna. K, Analysis of RCC and simcon buildings subjected to blast effects, international journal of civil engineering and technology 223-233 pp. Article ID: IJCIET 0704018 ISSN Print: 0976-6308 and ISSN Online: $097 \overline{6}-\overline{6} 16$, , Volume 7, Issue 4, July-August (2016).

[9] M Pavan Kumar and Rambabu k, Performance of RC space frame with vertical set back subjected to seismic and blast load using applied Element method, Disaster advances 10(5):1-13, May (2017).

[10] Jinwon Shin and Kyungkoo Lee, Blast Performance Evaluation of Structural Components under Very Near Explosion, KSCE Journal of Civil Engineering, pISSN 1226-7988, eISSN 1976-3808, June 14,(2017).

[11] Boyina sita, Rama Krishna and Jinka Chandra Sekhar, blast load analysis and effect on high rise structures, pp. 340-347, International Journal of Civil Engineering and Technology, Article ID: IJCIET 0906 039, ISSN Print: 0976-6308 and ISSN Online: 0976-6316, Volume 9, Issue 6, June (2018). 
[12] M Pavan Kumar and Rambabu k, response of regular RC space frame subjected to seismic and blast load using applied element method, Disaster advances 11(7):17-28, July (2018).

[13] M. Pavan Kumar, G.K. Chaitanya, K. Rambabu, "Collapse
Analysis of R.C Buildings subjected to Blast Load using AEM", The 18th International Symposium on New Technologies for Urban Safety of Mega Cities in Asia (USMCA - 2019), 9th -10th December 2019, Yangon Technological University, Yangon, Myanmar. 